\title{
ANALYSIS OF FACTORS AFFECTING THE DEVELOPMENT OF MICRO, SMALL AND MEDIUM ENTERPRISES (MSMES) IN RURAL AREAS
}

\author{
Dede Husni Mubarak \\ Institut Agama Islam Darussalam (IAID) Ciamis-Jawa Barat \\ Email: dedehusni.mubarok@iaid.ac.id \\ Maulida Hikmatul Husna \\ Institut Agama Islam Darussalam (IAID) Ciamis-Jawa Barat \\ Dudung Rahman Wahid \\ Institut Agama Islam Darussalam (IAID) Ciamis-Jawa Barat
}

\begin{abstract}
This study aims to elaborate on the factors that influence the development of micro, small and medium enterprises (MSMEs) in rural areas. This study uses a quantitative approach, because the data obtained is realized in the form of numbers and analyzed based on statistics. Based on the research method used, this research is an associativecausal research. Data collection techniques using a questionnaire with test requirements include validity test and instrument reliability test and normality test. Hypothesis test using Pearson Product Moment correlation, multiple correlation, simple regression, and multiple regression. The results of the study show (1) there is a significant influence of marketing factors on the development of MSMEs. (2) Working capital has a significant effect on the development of MSMEs. (3) The variables of marketing and capital have a significant effect on the development of MSMEs.
\end{abstract}

\begin{abstract}
Abstrak
Penelitian ini bertujuan untuk mengelaborasi faktor-faktor yang mempengaruhi perkembangan usaha mikro, kecil, dan mengah (UMKM) di wilayah pedesaan. Penelitian ini menggunakan pendekatan kuantitatif, karena data yang diperoleh diwujudkan dalam bentuk angka dan dianalisis berdasarkan statistik. Berdasarkan metode penelitian yang dilakukan, penelitian ini termasuk penelitian asosiatif-kausal. Teknik pengumpulan data menggunakan kuesioner dengan uji persyaratan meliputi uji validitas dan uji reliabilitas instrumen serta dan uji normalitas. Uji hipotesis menggunakan korelasi Product Moment Pearson, korelasi ganda, regresi sederhana, dan regresi berganda. Hasil penelitiaan menunjukkan (1) adanya pengaruh signifikan faktor pemasaran terhadap perkembangan UMKM. (2) Modal kerja berpengaruh signifikan terhadap perkembangan UMKM. (3) Variabel pemasaran dan modal berpengaruh signifikan terhadap perkembangan UMKM.
\end{abstract}

Keywords: Marketing, Capital Factor, MSME Development

\section{Introduction}

The necessities of life make humans referred to as economic actors, humans develop into many populations and spread in various parts of the world making the economy grow. The decline of Islam brought by the Prophet Muhammad, the religion of monotheism from Allah SWT which regulates all aspects of human life, including the economic aspect. Along with the birth of Islam, a new economic theory was born which 
was directly practiced by the Prophet Muhammad, namely Islamic economics, an economy based on the principle of God. In accordance with the word of God in the letter Al Israa: 31 which reads:

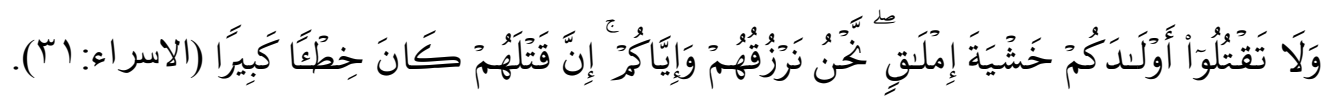

And do not kill your children for fear of poverty. it is we who will provide sustenance to them as well as to you. Indeed, killing them is a great sin (Q.S. Ali Isra, 17:31).

In developing countries, one of the main priorities in carrying out their country's activities is national development. So is the case with the Indonesian people. One of the things that is considered in national development in Indonesia is in the economic sector. With strong economic resilience, the state is able to meet the needs of its citizens equally for the welfare of its people.

Micro, Small and Medium Enterprises (MSMEs) are one of the business fields that can develop and be consistent in the national economy. Micro, Small, and Medium Enterprises also play a role in expanding job opportunities and provide broad economic services to the community, and can play a role in the process of equity and increase in people's income, encourage economic growth, and play a role in realizing national stability. Based on BPS data (2003), the population of small and medium-sized enterprises (SMEs) reached 42.5 million units or 99.9 percent of all business people in the country. SMEs make a significant contribution to employment, which is 99.6 percent. Meanwhile, the contribution of SMEs to Gross Domestic Product (GDP) is 56.7 percent. This figure continues to increase in line with the growth of MSMEs from year to year.

Although Micro, Small and Medium Enterprises have shown their role in the national economy, they still face various obstacles and constraints, both internal and external. As a business whose scope of business and members are (generally) small people with limited capital and limited managerial capabilities, MSMEs are very vulnerable to economic problems.

According to Nitisusastro (2012:41), the small business failure rate of $44 \%$ is caused by a lack of competence in the business world. What is meant by lack of competence here includes a lack of mastery of the business field being carried out and the ability to manage business activities both physically. The second cause of failure is due to the weak management ability which occupies a percentage of $17 \%$. The understanding of weak management skills here is the mastery of knowledge and experience in terms of managing human resources and other resources. The third source of failure is due to an imbalance of experience. The imbalance here includes the inability to balance between production, finance, marketing and spending activities.

Rifai (2013: 130-136) is of the view that there needs to be great attention to encourage the development of MSMEs seen from the factors related to the development of MSMEs themselves. 


\section{Theoritical Review}

\section{Marketing Concept}

According to Kotler and Keller (2008:5) "Marketing (marketing) is identifying and meeting human and social needs." According to Kotler and Keller (2008:5), marketing management occurs when at least one party in a potential exchange thinks about ways to achieve the response the other party wants. Marketing management is therefore seen as the art and science of selecting target markets and gaining, retaining, and growing customers by creating, delivering, and communicating superior customer value.

According to Kotler and Keller (2008:6-8) "marketing people market 10 types of entities, including goods, services, events, experiences, people, places, properties, organizations, information and ideas".

According to Kotler and Keller (2008:8), "A marketer is someone who is looking for a response, attention, purchase, support, donation from another party called a prospect. If two parties want to sell something to each other, Kotler and Keller call both parties a marketer. Kotler and Keller view that Marketers are skilled at stimulating demand for their company's products, but that view is too narrow to describe their job. Just as production and logistics professionals are responsible for supply management, marketers are responsible for demand management. Marketing managers seek to influence the level, timing, and composition of demand to achieve organizational goals.

According to Sutojo (2009:15), the market segment is part of the market as a whole. Whereas for every market company are individuals and or organizations that need their products and have the ability to buy them. The market segment consists of certain potential buyers (in large numbers) who meet the same criteria. These criteria can be in the form of certain demographic factors, level of purchasing power, age, race, ethnicity, gender, special situation factors and so on. Although not one hundred percent identical, potential buyers belonging to the same market segment usually have similar needs and desires for products. According to Sutojo (2009:16) most market companies can be grouped into two main market segments, namely: (1) final consumers or the consumer market, and (2) institutional buyers, or industrial market buyers.

\section{Capital Concept}

According to the Entrepreneurship Lecturer Team (2013:171), working capital is the amount of money needed to support the operation of a business. Without this amount of money, business operations will be disrupted, such as: unable to obtain raw materials, unable to provide sufficient inventory and insufficient cash for transactions. According to Hampton in Sukmadi (2010: 60), "Work management includes all funding functions related to the company's current estimate as well as with regard to the adequacy of current assets to cover current debts according to the level of risk. The working capital policy concerns the provisions and management guidelines in the context of managing capital".

Based on the description above, Sukmadi (2010:60-61) is of the view that working capital management has two important conflicting aspects, namely the rate of 
return (return) and risk (risk). The rate of return and risk can be analyzed based on the components in the balance sheet, both on the left and on the right. With regard to working capital, the left side of the balance sheet refers to assets consisting of cash, accounts receivable, and inventories. The right side of the balance sheet relates to funding with funding through loans, equity, and trade payables.

Working capital in terms of a company's needs, in general there are those that are used continuously or only incidentally. According to Sukmadi (2010:61) based on the nature of this use, working capital can be classified into two, permanent working capital and capital source. Permanent working capital are working capital that must always be there in the company to be able to carry out its functions, or in other words working capital that is continuously needed for the smooth running of the business. Permanent working capital can be divided into: (1) Primary working capital, namely the minimum working capital that must exist in the company to ensure the continuity of the company. (2) Normal working capital, namely the amount of working capital is influenced to carry out a normal (dynamic) production area. (3) Variable working capital, namely working capital whose amount varies according to changing circumstances. This working capital is divided into: (a) Seasonal working capital is working capital whose amount varies due to seasonal fluctuations. (b) Cycle working capital, namely working capital whose amount varies due to conjuncture fluctuations.(c) Emergency working capital, namely working capital whose amount varies due to a conjuncture emergency situation.

Secondly is the capital source. According to Nugroho in Ardianto's scientific work (2014) what is meant by sources of funding or capital is where the sources of funds that can be used to carry out investment activities come from. Sources of funding are classified into own capital and sources of loan funds. Own capital is a source of funds originating from the company's business owners while the source of loan funds is a source of funds originating from outside the company's operational activities such as debt to creditors.

\section{Concept of Micro, Small and Medium Enterprises}

According to Nitisusatro (2012:268) the business scale is divided into four groups, which include micro, small, medium and large businesses. The definition for each business scale is determined as follows: (1) the micro business are productive businesses owned by individuals and/or individual business entities that meet the criteria for micro-enterprises as regulated in this law. Small business is a productive economic business that stands alone, which is carried out by individuals or business entities that are not subsidiaries or not branches of companies that are owned, controlled, or become part either directly or indirectly of medium or large businesses that meet the criteria for small businesses as referred to in paragraph (1). referred to in this law. Medium enterprise is a productive economic business that stands alone, which is carried out by individuals or business entities that are not subsidiaries or branches of companies that are owned, controlled, or become part either directly or indirectly with Small Businesses or Large Businesses with total net assets or sales proceeds. annually as regulated in this Law. Big business is a productive economic business carried out by a business entity with a net worth or annual sales income greater than a medium-sized 
business, which includes state-owned or private national businesses, joint ventures, and foreign businesses conducting economic activities in Indonesia.

Criteria for Micro, Small and Medium Enterprises

Nitisusatro (2012:269) stated that the criteria for micro, small, medium and large scale businesses are regulated in Article 6. The criteria for business scale are based on two things, namely the amount of wealth or the amount of sales proceeds. The criteria as mentioned above are not static in nature, meaning that the nominal value can be changed in accordance with economic developments regulated by Presidential Regulation. Micro business criteria are: (1) have a net worth of at most Rp. 50,000,000.00 (fifty million rupiahs) excluding land and buildings for business premises; or (2) have annual sales of a maximum of Rp. 300,000,000.00 (three hundred million rupiah).

Small Business Criteria are: (1) have a net worth of more than Rp. 50,000,000.00 (fifty million rupiah) up to a maximum of Rp. 500,000,000.00 (five hundred million rupiahs) excluding land and buildings for business premises; or (2) have annual sales of more than Rp. 300,000,000.00 (three hundred million rupiah) up to a maximum of Rp. 2,500,000,000.00 (two billion five hundred million rupiah). Medium Enterprises Criteria are: (1) have a net worth of more than Rp. $500,000,000.00$ (five hundred million rupiah) up to a maximum of Rp. 10,000,000,000.00 (ten billion rupiahs) excluding land and buildings for business premises; or (2) have annual sales of more than Rp. 2,500,000,000.00 (two billion five hundred million rupiah) up to a maximum of Rp. 50,000,000,000.00 (fifty billion rupiah).

According to the category of the Central Statistics Agency (2016:1), small businesses are synonymous with small industries and home industries. BPS classifies industries based on the number of workers, namely: (1) home industries with 1-4 workers; (2) small industries with 5-19 workers; (3) medium-sized industry with 20-99 workers; (4) large industries with 100 workers or more.

According to Law no. 20 of 2008 concerning Micro, Small and Medium Enterprises in article 3, it is stated that micro and small enterprises aim to grow and develop their business in the context of building a national economy based on equitable economic democracy. This means that MSMEs play a role in national economic development through their contribution to GDP, job creation, and employment.

According to Tambunan (2002:73), the development of SMEs in Indonesia cannot be separated from various kinds of problems. There are several common problems faced by small and medium-sized entrepreneurs such as limited working capital and/or investment capital, difficulty in getting raw materials of good quality and affordable prices, limited technology, good quality human resources (management and production techniques), market information, and difficulties in marketing. The level of intensity and nature of these problems may differ not only according to the type of product or market served, but also between locations/between regions, between centers, between sectors/between sub-sectors or types of activities, and between business units within the same activity/sector. 


\section{Methods}

This study uses a quantitative approach, because the data obtained is realized in the form of numbers and analyzed based on statistics. Based on the research method carried out, this research includes research that is asking for the relationship between two or more variables or associative in the form of causal. Where causal according to Sugiyono (2016: 62) is a causal relationship. So here there are independent variables (variables that affect) and dependent (influenced).

This research was conducted in MSMEs in Margaluyu Village, Cikoneng District, Ciamis Regency. The total population of respondents (MSME owners) in Margaluyu Village spread over 4 Hamlets is 69 MSMEs. The number of objects that are examined or distributed is 30 MSMEs that have business permits. In theory, the respondent collection is included in Nonprobability Sampling with the Purposive Sampling technique. According to Sugiyono (2016: 126), purposive sampling is a sampling technique with certain considerations. For example, when conducting research on food quality, the sample data source is a person who is a food expert, or research on political conditions in an area, then the sample data source is a person who is a political expert.

In this study, researchers will use primary sources in data collection, namely data taken directly to respondents as the first hand collected with a questionnaire instrument. As for the data collection technique, the researcher will use a questionnaire (questionnaire).

According to Sugiyono (2016: 193), a questionnaire is a data collection technique that is carried out by giving a set of questions or written statements to respondents to answer. Questionnaires are an efficient data collection technique if the researcher knows with certainty the variables being measured and knows what to expect from the respondents. In addition, the questionnaire is also suitable for use when the number of respondents is large enough and spread over a wide area. Questionnaires can be in the form of closed or open questions/statements, can be given to respondents in person or sent by post, or the internet.

Analysis of the data used by researchers in the form of prerequisite tests and hypothesis testing. Prerequisite test in data analysis researchers used validity test, reliability test and data normality test. Then to test the hypothesis, simple correlation analysis is used to determine the coefficient criteria for each variable or partially, multiple correlation analysis is used to determine the coefficient criteria or the relationship of the independent variable with the dependent variable simultaneously, to see the effect of each independent variable on the dependent variable, simple regression analysis is used and Multiple regression analysis is also used to see the effect simultaneously.

\section{Results and Discussion}

Respondents who were taken as research objects were the owners of MSMEs or businesses in Margaluyu Village with a total of 30 MSMEs recorded. The author distributes questionnaires or questionnaires to 30 MSMEs spread across 4 hamlets, namely Village Hamlets totaling 11, Cisaray Hamlets totaling 7, Gunung Asih 1 Hamlets 
totaling 6 and Gunung Asih 2 totaling 6. However, only 28 questionnaires and 2 more questionnaires returned to the author's hands did not return because the respondent (business owner) was not willing to participate, the 2 questionnaires were from Gunung Asih Hamlet 1.

According to Sugiyono (2016:138) the steps that can be used in measuring questionnaire data are by multiplying the highest score in each statement item by the number of statements then multiplied again by the number of respondents. The total score from the data collection results is then divided by the number of ideal scores and multiplied by $100 \%$. The influence of each variable partially and simultaneously can be explained below.

The results of tests carried out using SPSS in a partial hypothesis test, namely the marketing factor on the development of MSMEs in Margaluyu Village, namely 0.204 , shows that there is no closeness or relationship between marketing and MSME development by 20.4 percent. The correlation between marketing and the development of MSMEs has a positive value but has a very weak correlation value. This shows that whether or not the marketing of MSMEs will not affect the development of MSMEs in Margaluyu Village. Then the effect can be seen from the magnitude of the $t$ value of 1.06o. The degrees of freedom used are df: , (n-k) or 0.05, (28-2) so that the table value is 1.706 . Because the value of $t$ count $<t$ table value or $1.060<1.706$, it can be concluded that the marketing variable does not have a positive influence on the development variable of MSMEs. Value of Sig. the marketing variable is 0.299 greater than alpha ( $\alpha$ ) or $0.299>0.05$ with a positive coefficient direction so it can be concluded that the marketing variable does not have a positive influence on the development of MSMEs in Margaluyu Village.

The partial hypothesis test, namely the capital factor on the development of MSMEs in Margaluyu Village, obtained a number of 0.627 , which is the Product Moment correlation coefficient with an asterisk $\left(^{* *}\right)$. The sign shows a significant correlation coefficient at a significant level of 0.01. so the number 0.627 shows that there is a close or relationship between capital and the development of MSMEs by 0.627 percent. The correlation between capital and the development of MSMEs in the table above has a positive value and has a sufficient correlation value. This shows that whether or not the capital in MSMEs is enough to influence the development of MSMEs in Margaluyu Village. Then to see whether or not the effect can be known on the test results which show the magnitude of the t-count value of 4.099. The degrees of freedom used are df: , (n-k) or 0.05, (28-2) so that the t table value is 1.706. Because the value of $t$ count $>t$ table value or 4,009 $>1,706$, it can be concluded that the capital variable has a positive influence on the development variable of MSMEs. Sig. modal variable is a number that indicates the magnitude of the error rate on the capital t value (4.009). If the value of $t$-modal is getting bigger, the value of the significance error is getting smaller. Because the value of Sig. the capital variable in the table above is 0.000 smaller than alpha $(\alpha)$ or $0.000<0.05$ with a positive coefficient direction so it can be concluded that the capital variable has a positive influence on the development of MSMEs in Margaluyu Village.

The test results from the simultaneous hypothesis test, namely the marketing and capital factors on the development of MSMEs in Margaluyu Village, it is known 
that the magnitude of the relationship between marketing (X1) and capital (X2) on the development of MSMEs ( $\mathrm{Y}$ ) is calculated by the correlation coefficient shown by the $\mathrm{R}$ value of $0.635, \mathrm{p}$. This shows a fairly temporary relationship, the simultaneous contribution or contribution of marketing and capital variables to the development of MSMEs is 0.403 , namely $40.3 \%$, while $59.7 \%$ is determined by other variables. Then seen from the effect, the calculated $\mathrm{F}$ value obtained from the results of regression testing shows a value of 9.171. With df: , (k-1), (n-k) or 0.05, (3-1), (28-3), the F table value is 3.385. Because $\mathrm{F}$ count $>\mathrm{F}$ table or $9.171>3.385$, it can be concluded that the regression equation model that is formed includes suitable criteria or fit. It is known that the calculated $\mathrm{F}$ value is 9.171. It turns out that the error rate or probability is 0.001 which means it is smaller than 0.05. So it can be concluded that the independent variables are simultaneously able to explain changes in the dependent variable or the model is declared suitable and Ha can be accepted.

\section{Conclusion}

Based on the discussion that has been described regarding the Effect of Marketing and Capital Factors on the Development of MSMEs in Margaluyu Village, Cikoneng District, Ciamis Regency, the following conclusions can be drawn: (1) The influence of marketing factors on the development of MSMEs from Simple Regression data analysis shows that the magnitude of the t-count value is 1.060 and the value of $t$ table is 1.706 from df: , (nk) or $0.05(28-2)$. So that the value of $t$ count $<t$ table value or $1.060<1.706$, then from the Sig test. It is obtained that $0.299>$ aplha or $0.299>$ 0.05 with a positive coefficient direction. The result is that there is no effect, namely Ho is accepted and Ha is rejected. Then from the simple correlation data analysis of 0.204, it shows that the correlation value is very weak. (2) The effect of capital factors on the development of MSMEs from Simple Regression data analysis shows that the magnitude of the t-count value is 4.099 and the magnitude of the $t$-table value is 1.706 from df: , (n-k) or 0.05 (28-2). So that the value of $t$ count $>t$ table value or 4,099 > 1,706 , then from the Sig test. It was obtained that $0.000<$ aplha or $0.000<0.05$ with a positive coefficient direction, the result is that there is an effect, namely Ha is accepted and Ho is rejected. Then from the simple correlation data analysis of 0.627 , it shows that the correlation value is sufficient. (3) The influence of marketing and capital factors on the development of MSMEs from the analysis of Multiple Regression data shows that the magnitude of the $F$ test results can be known the value of $F=9.171$ and the $\mathrm{F}$ table value is 3.385 from df: , (k-1), (nk) or 0.05 , (3-1), (28-3). It is obtained that $\mathrm{F}$ arithmetic $>$ F table or $9.171>3.385$ then the significance is $0.001<$ alpha or $0.001<$ 0.05 with a positive coefficient direction, it can be concluded that the regression equation model formed includes suitable criteria and it is stated that there is an influence, namely $\mathrm{Ha}$ is accepted and $\mathrm{Ho}$ is rejected. Then from the analysis of multiple correlation data of 0.635 , it shows a sufficient correlation value. This result can also be seen from the $\mathrm{R}$ Square of 0.423 from the correlation coefficient (R) of 0.651. R Square is called the coefficient of determination, which in this case is $42.3 \%$, meaning that the marketing and capital variables are able to explain $42.3 \%$ of the development of MSMEs while the rest is explained by other variables or other factors. 


\section{REFERENCES}

Badan Pusat Statistika. (2003) Tabel Perkembangan UMKM. Di ambil dari https://www.bps.go.id/linkTabelStatis/view/id/1322. Diakses tanggal 4 April 2016.

Badan Pusat Statistika. (2016). Perusahaan Industri Pengolahan. Di ambil dari https://www.bps.go.id/subjek/view/id/g. Diakses tanggal 2 April 2016

Kottler dan Keller. (2008). Manajemen Pemasaran Edisi 13 Jilid 1. Jakarta: Erlangga.

Kewirausahaan, Team Dosen. (2013). Modul Kewirausahaan. Jakarta: Mandiri Perpustakaan.

Nitisusastro, Mulyadi. (2012). Kewirausahaan dan Manajemen Usaha Kecil. Bandung: Alfabeta.

Rifa'I, Bachtiar (2013). Efektivitas pemberdayaan usaha mikro kecil dan menegah (UMKM)/ jurnal Kebijakan dan manajemen publik, 1(1), 130-136. Diambil dari http://journal.unair.ac.id/download-fullpapers 16\%20Baktiar_KMP\%20V1\%20N1\%2OJan-April\%202013.pdf

Sugiyono. (2016). Metode penelitian kombinasi (mixed methods). Bandung: Alfabeta.

Sutojo, Siswanto. (2009). Manajemen Pemasaran (Untuk Eksekutif Non-Pemasaran). Jakarta: Damar.

Sukmadi. (2010). Pengantar Ekonomi Bisnis. Bandung: Humaniora.

Tambunan, Tulus. (2002). Usaha Kecil dan Menengah di Indonesia: Penting. Jakarta: Penerbit Salemba Empat 
